\title{
PENTINGNYA PENDIDIKAN AGAMA ISLAM DALAM MEMBENTUK KARAKTER ANAK
}

\author{
M. Abdul Somad ${ }^{1}$ \\ ${ }^{1}$ Universitas Pendidikan Indonesia Bandung \\ *Corresponding email: somad100@upi.edi
}

Naskah diterima: 14 Juli 2021| Disetujui: 11 Agustus2021 | Diterbitkan: 13 Agustus 2021

\begin{abstract}
This research is motivated by our curiosity and public anxiety over the various characters of a child or individual in Indonesia. The hope of the community is big enough to make a child or individual able to get good character education, so that he becomes a human with character, has noble character and can live his life in accordance with Islamic law. Seeing this, it is necessary to conduct a study of this incident by taking samples from various examples in the community who are or have undergone the process of educating their children. Researchers conducted surveys and asked questions with people around and got various kinds of responses that were quite diverse. To achieve this goal, this research uses qualitative-descriptive research methods with literature study techniques. The results of this study obtained data and facts that character education from an early age is very important, by choosing the right methods according to Islamic teachings so that children become human beings who are educated in faith, science, charity, have broad insight, become good citizens and noble character that can benefit all mankind.
\end{abstract}

Keywords: Education, Character Education, Islam.

Abstrak: Penelitian ini dilatar belakangi oleh rasa penasaran penulis dan keresahan masyarakat atas berbagai macam karakter seorang anak atau individu yang ada di Indonesia. Harapan masyarakat cukuplah besar untuk menjadikan seorang anak atau individu bisa mendapatkan pendidikan karakter yang baik, agar menjadi manusia yang berkarakter, berbudi pekerti luhur, dan dapat menjalankan kehidupannya sesuai dengan syariat Islam. Melihat hal tersebut, perlu kiranya dilakukan kajian terhadap kejadian ini dengan mengambil sampel dari berbagai contoh di masyarakat yang sedang atau sudah menjalani proses mendidik kepada anaknya. Peneliti melakukan survei dan tanya jawab dengan orang-orang di sekitar dan mendapatkan berbagai macam respon yang cukup beragam. Untuk mencapai tujuan tersebut, penelitian ini menggunakan metode penelitian kualitatif-deksriptif dengan teknik studi pustaka. Hasil dari penelitian ini diperoleh data dan fakta bahwa pendidikan karakter sejak dini sangatlah penting, dengan memilih metode-metode yang tepat sesuai ajaran Islam agar anak menjadi manusia yang terdidik dalam iman, ilmu, amal, memiliki wawasan yang luas, menjadi warga negara yang baik, dan berakhlak mulia yang dapat bermanfaat bagi seluruh umat manusia.

Kata kunci: Pendidikan, Pendidikan Karakter, Islam. 


\section{PENDAHULUAN}

Pendidikan merupakan sebuah proses pembelajaran, keterampilan, dan kebiasaan sekelompok orang yang diturunkan dari satu generasi ke generasi yang umumnya dilakukan melalui proses pengajaran. Pendidikan pada dasarnya juga sebuah upaya yang bertujuan mengembangkan seluruh potensi dalam mempersiapkan karakter seseorang agar dapat menyikapi berbagai hal yang akan dihadapi dalam hidupnya. Dengan demikian, pendidikan merupakan sarana dalam menginternalisasikan nilai-nilai ajaran hidup dan kehidupan kepada seseorang dalam rangka membentuk karakter serta kepribadian ke arah yang lebih baik (Parhan, 2018).

Pendidikan dapat dikatakan ideal apabila memperhatikan berbagai macam dimensi, seperti dimensi intelaktual, spiritual, dan sosial. Tentunya dengan memperhatikan kapasistas dan potensi fisik, serta realitas dari peserta didik untuk bersinergi dengan baik (Syam, 2016). Sehingga seluruh unsur dan perangkat pendidikan sangat diperlukan untuk mendukung suksesnya seluruh program dan kegiatan pembelajaran yang akan dilakukan, seperti membina guru dengan baik, menata lingkungan pembelajaran, membina kesiapan mental peserta didik, sampai merencanakan program-program yang akan dan sedang dilakukan dengan sebaik mungkin. Kesiapan dan perencanaan yang matang serta bersinergi dengan baik akan memberikan ketenangan dan suasana belajar yang nyaman, sehingga mempengaruhi kepribadian anak.

Kepribadian anak dipengaruhi oleh pola asuh yang diberikan dalam kehidupan sehari-hari termasuk dalam lingkungan pendidikan dan lingkungan keluarga (Parhan \& Kurniawan, 2020). Orang tua memiliki peran yang sangat besar dalam mengarahkan dan membentuk karakter anak, sehingga orang tua harus jeli dan bijak untuk memberikan pola asuh yang tepat dan dapat diterapkan untuk anaknya. Apabila hal ini dilakukan dengan baik, maka orang tua dapat bersinergi dengan anak, lingkungan pendidikan, lingkungan rumah, dan perkembangan serta kepribadian anak yang berlandaskan sikap religiusitas yang baik agar dapat tumbuh menjadi anak yang memiliki kepribadian yang baik (Muthmainnah, 2012).

Salah satu pendidikan yang harus diperhatikan untuk anak dalam lingkungan keluarga dan lingkungan pendidikan adalah mendapat porsi yang tepat dan sesuai perkembangannya dalam pendidikan agama, hal ini harus menjadi perhatian yang serius karena menjadi pondasi dalam membentuk karakter dan kepribadian serta pola pikirnya. Lingkungan keluarga lagi-lagi menjadi lingkungan pertama dan utama dalam dalam membentuk kepribadian anak (Parhan \& Kurniawan, 2020). Dengan dilandasi nilai-nilai spiritualitas yang bersumber pada nilai-nilai agama Islam, diharapkan dapat menjadi filter untuk anak-anak dalam menghindari pelanggaran moral, tumbuh menjadi anak yang memiliki kepribadian yang utama sesuai dengan tuntutan ajaran Islam, mampu 
tumbuh menjadi pribadi yang sinergi dalam iman, ilmu dan amal shalih, memiliki paradigm berpikir yang luas, menjadi umat beragama yang religius, berakhlak mulia, serta menjadi warga negara yang baik (Rufaedah, 2020).

Menanamkan nilai-nilai spiritual yang bersumber dari ajaran agama termasuk dalam bidang pendidikan yang harus menjadi perhatian serius dari keluarga kepada anak-anaknya, hal ini dapat menjadikan kokohnya pondasi dan filter yang bersifat naluri untuk anak, yang dapat membangkitkan kesadaran dan kekuatan spiritual bagi anak sedini mungkin (Tahang, 2010), sehingga peran keluarga dalam menciptakan lingkungan keluarga yang kondusif dalam menanamkan nilai-nilai moral dan spiritual menjadi sangat penting dalam membentuk kepribadian dan karakter anak (Azis, 2017). Dengan demikian, peran orang tua sangatlah penting untuk membentuk karakter serta kepribadian untuk anaknya. Kepribadian seorang anak sangat dipengaruhi oleh bimbingan dan pendidikan orang tua dalam mengarahkan dan memberikan pendidikan. Hal ini dikarenakan pendidikan agama yang ditanamkan sedini mungkin untuk anak-anak dapat menjadi pilar utama bagi anak dalam membentuk karakter dan kepribadian yang sesuai dengan nilai-nilai Islam agar mewujudkan generasi yang berakhlakul karimah (Perni, 2019).

Pendidikan agama merupakan usaha yang dilakukan dengan logis dan sistematis, dan kadang bersifat pragmatis yang bertujuan untuk membantu anak agar dapat hidup selaras dengan nilai ajaran agamanya (Djaelani, 2013b). Oleh karena itu, apabila dalam keluarga memeluk agama Islam, maka kemungkinan besar pendidikan agama yang akan diberikan kepada anak adalah pendidikan agama Islam. Sementara itu (Muhaimin, 2012) memberikan pandangannya mengenai pendidikan Islam, menurutnya pendidikan Islam merupakan pendidikan yang berdasarkan nilai-nilai ajaran Islam atau sistem pendidikan yang Islami, yakni pendidikan yang dipahami, dikembangkan, dan disusun dari ajaran serta nilai-nilai fundamental yang terkandung dalam sumber dasarnya yaitu Al-Qur'an dan AsSunnah. Dalam pengertian ini pendidikan Islam dapat berupa sebuah pemikiran atau teori pendidikan yang didasarkan dan dikembangkan dari sumber-sumber dasar yaitu Al-Qur'an dan As-Sunnah. Pendidikan Islam dapat dilihat dari perspektif pendidikan ke-Islamaan atau pendidikan agama Islam, yakni upaya mendidik agama Islam dan nilai-nilainya agar menjadi way of life (pandangan dan sikap hidup) seseorang untuk keselamatan dan kesejahteraan hidup di dunia dan akhirat (Parhan \& Sutedja, 2019)

Pendidikan agama dalam keluarga merupakan sebuah proses membina sekaligus mendidik anak agar menjadi dewasa dengan memiliki kesadaran dan tanggung jawab secara moral, agama, maupun sosial kemasyarakatan. Pada masa remaja, pendidikan agama yang diberikan oleh orang tua dapat berfungsi untuk mengurangi tindakan dan perilaku anak dalam menghindari kenakalan remaja dengan 
menanamkan kedisiplinan sedini mungkin. Banyaknya penyelewengan nilai-nilai agama oleh seorang anak menjadi bukti dan sebuah cerminan terhadap kurangnya penanaman nilai agama pada diri anak sedini mungkin. Hal ini dikarenakan bahwa pertumbuhan otak anak ditentukan oleh orang tua dalam memberikan asupan dan asuhan, serta menstimulasi anak sedini mungkin yang lebih dikenal dengan istilah critical period. Peran orang tua dalam mendidik anak sedini mungkindapat dilakukan dengan cara menjadikan orang tua dalam melakukan pendidikan yang utama dan pertama, menumbuhkembangkan kreativitas buat anak, serta menstimulus perkembangan otak dan kemampuan anak dengan mengoftimalkan seluruh potensi yang dimilikinya (Novrinda et al., 2017).

Islam sangat memperhatikan perkembangan anak, moral, akhlak, bahkan keutamaan manusia dapat dilihat dari moral dan akhlak yang ditunjukannya. Oleh karena penting dan tingginya nilai akhlak manusia dalam Islam, Rasul diutus ke dunia salah satunya adalah untuk menyempurnakan akhlak umat manusia dan menjadikan akhlak sebagai ukuran dari keimanan seorang hamba. Beliau bersabda "Orang mukmin yang paling sempurna imannya adalah yang paling baik akhlaknya." (H. R. Imam Abu Dawud dan Imam Tirmidzi). Di dalam syariat Islam, keagungan akhlak sangat berkaitan dengan keimanan, bahkan tidak bisa dipisahkan dari keimanan, sehingga komprehensif antara, iman, ilmu, dan amal diaktualisasikan dengan akhlak mulia dalam kehidupan manusia (Alawi, 2019). Selain itu, dalam ajaran Islam terdapat nilai utama yang harus menjadi perhatian untuk orang tua, yaitu adab dan akhlak yang disampaikan melalui keteladanan.

Dewasa ini kita sering mendengar keluhan orang tua, guru, maupun orang yang berkecimpung dalam dunia anak, terutama yang berhadapan langsung dengan anak yang berusia belia bahkan remaja pun banyak yang sulit dikendalikan. Sifat nakal, keras kepala, berkata kasar, atau hal lainnya yang dapat mengganggu ketertiban umum dan merugikan anak itu sendiri, sehingga penulis merasa tertarik untuk lebih mendalami dengan mencoba meneliti lebih jauh mengenai pentingnya nilai-nilai ajaran agama yang dituangkan dalam pendidikan agama Islam untuk membentuk karakter anak, yang diharapkan akan menjadi sumbangan pemikiran dan acuan dalam pendidikan anak yang berlandaskan nilai-nilai spiritual, sehingga anak menjadi manusia yang terdidik dalam iman, ilmu, amal, memiliki wawasan yang luas, berakhlak mulia, serta mampu tampil sebagai pribadi yang bermanfaat untuk agama, bangsa, negara, dan seluruh umat manusia.

\section{METODE}

Penelitian ini menggunakan pendekatan kualitatif deskriptif dan survei. Penelitian kualitatif merupakan sebuah penelitian yang dilakukan oleh peneliti dengan mengumpulkan data, mengolah data, menganalisis, dan menafsirkan hasil data penelitian yang sebelumnya diperoleh melalui 
beberapa teknik, di antaranya melakukan observasi, interview atau wawancara, analisis isi, serta metode lain yang sesuai dalam menggali dan menemukan data (Setyosari, 2016). Peneliti melakukan penelitiannya didasarkan pada strategi, paradigma, serta implementasi secara kualitaitif. Tujuan dari pendekatan ini adalah untuk mendeskripsikan dan menjelaskan suatu peristiwa, keadaan, atau segala objek yang terkait dengan variabel-variabel yang dituangkan dengan angka, dimaknai dengan katakata, kemudian diberikan interpretasi dan analisis secara mendalam. Sementara penelitian deskriptif yaitu suatu penelitian yang berusaha untuk menuturkan pemecahan masalah yang ada berdasarkan data-data, menganalisis dan menginterpretasi. Selain itu juga dapat bersifat komperati dan korelatif. Tujuan penelitian ini adalah untuk pemecahan masalah secara sistematis dan faktual mengenai faktafakta dan sifat-sifat populasi (Hardjasujana \& Ahmadslamet, 1999).

Pengumpulan data dilakukan dengan menggunakan metode survei responden dengan menyebar kuisioner/angket meliputi orang yang sudah berumah tangga dan memiliki anak. Pengambilan sampel responden dilakukan dengan menyebar kuisioner/angket dengan menggunakan link google form. Tujuannya adalah untuk mengetahui seberapa penting peran Islam menurut para responden dalam membentuk karakter seorang anak. Link google form juga bertujuan untuk menampung aspirasi para orang tua dalam menyikapi kejadian-kejadian di zaman sekarang, salah satunya adalah banyaknya seorang anak yang sering mengucapkan kata-kata kasar saat mengobrol kepada teman sebayanya baik secara langsung ataupun tidak langsung.

\section{HASIL DAN PEMBAHASAN}

Hasil survei mengenai pentingnya pendidikan agama Islam dalam membentuk karakter anak yang diperoleh dari hasil pengisian responden terhadap kuesioner yang diberikan kepada para orang tua, peneliti mendapatkan respon sebanyak 22 responden. Hal tersebut dilakukan dengan cara memberikan kuesioner/angket yang berisi 5 (lima) pertanyaan. Pertama, menurut Bapak/Ibu, apakah Islam itu penting dalam proses pembentukan karakter atau mendidik seorang anak? apa alasannya? Kedua, menurut Bapak/Ibu, apakah lembaga pendidikan Islam seperti TPA turut serta dalam proses itu? Apa alasannya? Ketiga, seberapa sering Bapak/Ibu melihat dan mendengar seorang anak yang berkata kasar atau melanggar aturan/norma yang berlaku? Keempat, menurut Bapak/Ibu, apa penyebab seorang anak bisa berkata kasar atau melanggar aturan/norma yang berlaku? Kelima, adakah yang ingin Bapak/Ibu sampaikan/usulkan mengenai pendidikan Islam dalam pembentukan karakter?

Berdasarkan hasil pengelolaan angket pada pertanyaan nomor satu dari 22 responden, dapat diperoleh data bahwa betapa pentingnya Islam dalam proses pembentukan karakter seorang anak. 
Karena Islam adalah pendidikan yang sangat berpengaruh bagi kehidupan anak di masa depan. Pendidikan Islam juga memiliki peran yang sangat penting untuk membentuk karakter dan kepribadian yang baik bagi anak, terutama di era globalisasi. Sebagai orang tua sebaiknya lebih menitikberatkan ilmu pendidikan Islam kepada anak. Penanaman akhlak dan moral sangat diperlukan di usia dini karena anak cenderung lebih mudah untuk meniru, sehingga mudah untuk membentuk kepribadian yang baik di masa depan.

Hal ini sesuai dengan hadist Nabi yang artinya "Aku diutus di muka bumi untuk menyempurnakan akhlak" (H.R. Bukhari dan Muslim). Dapat diartikan bahwa moral dan akhlak merupakan sesuatu yang sangat penting untuk diterapkan kepada anak sedini mungkin, karena akhlak merupakan esesnsi dasar ajaran Islam setelah iman, ilmu, dan syariah. Sehingga dengan adanya pendidikan akhlak sedini mungkin, maka akan terbina dan tertanam karakter anak yang memiliki mental dan jiwa kemanusiaan yang baik serta berakhlakul karimah. Oleh karena itu, anak akan tumbuh dan berkembang menjadi pribadi yang sempurna secara moral, terbuka bagi hadirnya nilainilai kebaikan, dan menutup diri dari segala keburukan (Setiawan, 2017). Keutamaan akhlak di dalam agama merupakan bagian yang tidak dapat dihilangkan dalam kehidupan manusia, agar dapat membedakannya dengan makhluk lain yang ada di muka bumi.

Akhlak menjadi hal yang sangat penting untuk manusia dalam mengemban amanah sebagai pemimpin di bumi ini (khalifatullah). Dengan akhlak mulia Allah menitipkan alam dunia beserta isinya untuk dikelola dengan baik oleh manusia. Dengan dibekali akal pikiran yang berfungsi untuk membedakan antara mana yang hak dan mana yang batil, mana yang baik mana yang buruk, mana yang halal dan mana yang haram (Mansur, 2000). Dalam ajaran Islam keutamaan akhlak untuk anak sangat dipengaruhi oleh bimbingan dan pendidikan yang diberikan oleh orang tua. Bahkan pendidikan yang diberikan semenjak pra nikah, masa kandungan, sampai pada anak dewasa tidak luput dari peran orang tua dalam memberikan pendidikan. Asupan nutrisi yang baik, pemberian nama yang baik, memelihara dan menjaga anak dengan menyeluruh, seperti menjaga mental, spiritual, fisik, fsikis, pergaulan, pendidikan serta perkembangannya. Selain itu orang tua memiliki peran yang sangat penting dalam menanamkan dan menginternalisasikan nilai-nilai agama dan moral untuk membentuk karakter positif anak (A'yun et al., 2015)

Berdasarkan hasil pengelolaan angket pada pertanyaan nomor dua dari 22 responden, diperoleh data bahwa lembaga pendidikan Islam seperti TPA (Taman Pengajian Anak) turut serta dalam proses pembentukan karakter anak. Hal itu karena mereka mendapat pengetahuan dan pendidikan lebih yang belum tentu didapatkan di rumah. Di TPA pula anak dapat mulai belajar untuk bersosialisasi dengan lingkungan di sekitarnya. Selain itu, anak dapat mulai mencari dan berteman dengan sebayanya. Hal 
ini dapat diketahui bahwa pembentukan akhlak kepada anak dapat diartikan dengan usaha yang disengaja serta sungguh-sungguh sebagai upaya mempersiapkan anak untuk memiliki kepribadian yang baik melalui sarana pendidikan serta pembinaan yang terencana, serta terprogram dengan baik, serta dilaksanakan dengan serius dan sungguh-sungguh (Husin, 2016).

Keluarga menjadi bagian yang utama karena pendidikan yang diberikan dalam keluarga merupakan madrasah utama dan pertama untuk tumbuh kembanga anak. Keluraga berperan menjadi sumber pendidikan yang pertama bagi anak dalam mengokohkan keyakinan beragama, nilai-nilai moral, memberikan tauladan yang baik, memberikan keterampilan dan pengetahuan yang mempuni sebagai pondasi bagi anak untuk dijadikan pondasi dalam berinteraksi dengan lingkungan, baik secara individual maupun komunal. Selain menjadi anugrah, anak juga sebagai amanah yang harus dipersiapkan pendidikannya sedini mungkin (Erzad, 2018).

Pendidikan yang harus dipersiapkan sedini mungkin tentu saja yang selaras dengan ajaran agama, terutama ajaran Islam. Nilai-nilai Islam sangat universal dan menjadi rahmat untuk seluruh alam karena kebaikan dan kebenarannya bersifat menyeluruh dan global (Parhan, Islamy, et al., 2020). Tujuan dari pendidikan Islam yang ditanamkan sedini mungkin adalah agar anak memiliki pengetahuan dan gambaran yang komprehensif tentang ajaran Islam secara utuh dan menyeluruh. Hal ini akan ditampilkan anak ketika dia bergaul dengan teman dan berinteraksi dalam kehidupannya, yang kemudian ditunjukan melalui sikap, perilaku, penampilan, perbuatan, dan kebiasaan sehari-hari. Ketika nilai-nilai Islam menjadi landasan dalam membentuk karakter anak, maka segala perbuatan anak akan selaras dengan aturan dan syariat Islam (Djaelani, 2013a). Dengan demikian akhlak sangat perlu untuk dibiasakan dan ditanamkan kepada anak melalui berbagai cara, misalnya dengan latihan membaca dan mengkaji Al-Qur'an, saum (baik wajib maupun sunah), salat (baik fardu, maupun sunah), menekankan pentingnya menjaga tali silaturahim dengan sesama, keluarga, dan masyarakat. Anak yang sudah terbiasa dilatih demikian akan lebih mudah dalam melakukan amal baik, sehingga menjadi kebiasaan yang terus terulang dan bisa membentuk karakter utama bagi anak (Djaelani, 2013b).

Masa anak merupakan masa yang sangat berarti dan menjadi masa yang sangat penting dalam menanamkan nilai-nilai kebaikan, trutama yang berlandaskan kepada nilai-nilai agama. Usia anak antara 0-6 tahun merupakan masa pertumbuhan dan perkembangan. Pada masa ini para ahli menyebutnya dengan masa emas (golden age) untuk perkembangan dan memaksimalkan kinerja intelektualnya, sehingga dapat menyerap seluruh informasi dengan baik dan maksimal. Pada usia tersebut seorang anak akan mengalami perubahan secara kualitatif yang ditandai dengan meningkatnya ukuran serta struktur otak dan fisik, terutama dalam memaksimalkan fungsional di 
samping material (Towoliu et al., 2021). Sehingga pertumbuhan anak sangat erat kaitannya dengan semakin bertambahnya perangkat fisik yang baik, sementara perkembangan berkaitan dengan fungsinya.

Maka dari itu pendidikan akhlak dalam membentuk karakter anak harus ditanamkan sedini mungkin, karena merupakan suatu kesatuan yang terintegrasi dengan ajaran agama Islam. Akhlak dalam Islam memberi landasan bagaimana kaidah-kaidah serta aturan mengenai benar-salah, baikburuk, hak dan batil yang berlandaskan kepada ajaran yang bersumber dari Allah SWT yang dituangkan dalam Al-Qur'an yang dicontohkan langsung oleh Rasulullah SAW dalam melaksanakannya, sehingga karena anak dibiasakan dan ditanamkan karakter baik yang bersumber kepada nilai-nilai agama, maka apapun, di mana pun, dan kapan pun perbuatannya akan selaras dengan aturan agama. Ketika dikatakan baik oleh aturan Allah maka sudah pasti memiliki eksistensi dan esensi nilai-nilai kebaikan di dalamnya, begitu pun sebaliknya. Segala keburukan dan kejelekan akan berdampak buruk terhadap diri dan lingkungannya, tentunya esensinya adalah sebuah keburukan (Sari, 2017).

Berdasarkan hasil pengelolaan angket pada pertanyaan nomor tiga dari 22 responden, didapatkan hasil bahwa $64 \%$ orang tua menjawab sering dan $27 \%$ menjawab sering sekali mendengar anak-anak mereka berkata kasar atau melanggar aturan yang berlaku. Hal ini membuktikan bahwa pendidikan agama Islam dalam pembentukan karakter anak harus ditanamkan sedini mungkin yang dimulai dari lingkungan keluarga. Hal itu karena keluarga merupakan pendidikan yang pertama dan utama untuk tumbuh kembang anak. Pendidikan keluarga untuk anak dilakukan untuk menghindari hal-hal yang tidak sesuai dengan aturan Islam. Hal tersebut dapat di lihat seperti dalam diagram di bawah ini.

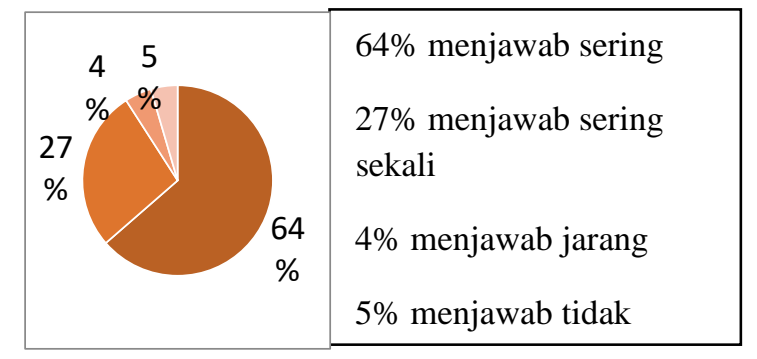

Gambar 1. Diagram seberapa sering orang tua mendengar anak berkata kasar.

Pendidikan agama Islam yang ditanamkan sedini mungkin kepada anak merupakan segala usaha sadar dan terencana yang dilakukan melalui proses panjang dan memiliki tujuan untuk mempersiapkan kualitas anak baik jasmani maupun rohani menuju kesempurnaan (Sukring, 2013). Hal yang sama juga dikemukakan (Ramayulis, 2012) yang memberikan pandangan mengenai pendidikan Islam untuk anak. Menurutnya, pendidikan agama Islam merupakan suatu bimbingan 
terhadap pertumbuhan jasmani dan rohani melalui hikmah, dengan cara mengasuh, mengawasi, mengajarkan, melatih, mengarahkan, dan mengenalkan anak tentang aturan dan tuntunan berdasarkan Islam. Sehingga segala kegiatan yang dilakukan oleh orang tua dapat membantu anak dalam menanamkan dan menumbuh kembangkan ajaran Islam dan nilai-nilai ajaran Islam untuk dapat dijadikan sebagai pandangan hidupnya. Hal tersebut dapat diwujudkan dalam sikap hidup dan dikembangkan dalam keterampilan hidup sehari-hari.

Pentingnya pendidikan agama Islam dalam membentuk karakter anak yang dilakukan oleh orang tua pada hakikatnya merupakan sebuah usaha sadar dan terencana untuk mempersiapkan anak dalam memahami, meyakini, menghayati, dan mengamalkan ajaran agama Islam melalui kegiatan bimbingan, latihan, dan pengarahan. Hal tersebut dapat dilakukan melalui proses panjang dan memiliki tujuan dengan mengoptimalkan potensi dasar (fitrah) anak melalui proses intelektual dan spiritual berlandaskan nilai-nilai ajaran agama Islam yang bersumber dari Al-Qur'an dan As-Sunnah untuk mencapai kebahagiaan hidup di dunia dan akhirat. Sehingga anak tumbuh dan berkembang menjadi manusia yang terdidik baik intelektualnya maupun spiritualnya yang berlandaskan nilai-nilai keimanan dan ilmu pengetahuan. Semua itu diaktualisasikan melalui amal perbuatan dengan memiliki wawasan yang luas sebagai warga negara yang baik dan berkahlah mulia, serta menjadi manusia yang bermanfaat untuk seluruh umat manusia yang ada di dunia (Parhan \& Sutedja, 2019).

Berdasarkan hasil pengelolaan angket pada pertanyaan nomor empat dari 22 responden diperoleh data bahwa penyebab seorang anak berkata kasar atau melanggar aturan/norma yang berlaku yaitu kurangnya penguatan dari sisi agama, kurangnya pengetahuan pendidikan moral yang diberikan pada anak, serta kurangnya perhatian dan kasih sayang dari keluarganya sendiri. Tidak sedikit anak yang kurang perhatian dari orang tua. Selain itu, pergaulan di lingkungan anak juga dapat membawa pengaruh buruk bagi kepribadian si anak.

Nilai-nilai agama Islam dalam membentuk karakter anak memerlukan proses internalisasi sehingga dapat menjadi karakter yang menyatu dengan dirinya. Proses internalisasi tersebut dapat dilakukan dalam keluarga melalui peran serta orang tua yang dilakukan secara alami tanpa rekayasa. Beragam cara dapat dilakukan oleh orang tua untuk menginternalisasikan nilai-nilai agama agar menjadi karakter baik untuk anak, yaitu dengan menggunakan nasihat yang baik, pembiasaan yang konsisten, dan keteladanan dari kedua orang tuanya. Selain itu, adanya reward dan punishment sebagai motivasi dan hukuman untuk anak juga dapat menumbuhkan karakter yang baik bagi anak (Setiardi, 2017). Proses internaliasi nilai-nilai pendidikan agama Islam dalam membentuk karakter anak memberikan arti bahwa pada hakikatnya hal ini merupakan sebuah upaya dalam menanamkan perasaan, sikap, dan keyakinan, yang bersumber dari agama agar menjadi bagian dalam diri anak 
(Parhan, Faiz, et al., 2020). Adanya proses belajar yang dilakukan antara orang tua dan anak dalam menanamkan sikap, pengetahuan, keterampilan, dan perasaan menjadi standar untuk kehidupan anaknya kelak, yang bersumber dari ajaran agama melalui nasihat, pembiasaan, dan keteladanan (Gade, 2012). Hal tersebut sesuai dengan apa yang dikatakan Rasulullah SAW "Sebaik-baik kamu adalah yang paling baik terhadap keluargamu dan aku adalah yang paling baik dalam memperlakukan keluargaku." (HR. Ibnu Hibban).

Selain itu, (Hakam, 2016) juga mengemukakan konsepnya tentang nilai. Menurutnya, nilai yang dicari oleh manusia tidak statis dan tidak berakhir pada penemuannya. Semakin didekati, nilai semakin meluaa. Semakin dikuasai, nilai semakin tumbuh dan berkembang memperkaya dirinya tanpa batas. Nilai itu kaya, melampaui kemampuan manusia untuk memahami dan menguasainya. Semakin nilai diketahui, semakin disadari betapa banyaknya nilai yang belum dikuasai. Oleh karena itu, pendidikan nilai berlangsung sepanjang hayat. Tahap-tahap internalisasi nilai antara lain: 1). Informasi moral (Moral information level), 2) Keyakinan moral (Moral belieflevel), 3) Sikap moral (Moral Attitude level), 4) Nilai moral (Moral value level), 5) Karakter/kepribadian moral (Moral character/personality level), 6) Jati diri bermoral (Moral dignity level). Proses penginternalisasian nilai diawali dengan penyampaian informasi, yaitu memperkenalkan seseorang pada gagasan nilai yang akan diinternalisasikan. Gagasan nilai tersebut berbentuk standar, aturan, hukum, rumus atau dalil yang bersifat normatif atau diformulasi dalam bentuk kisah-kisah problematis (dilema moral). Hal tersebut juga sebagai stimulus yang membutuhkan respon atau solusi yang bermuatan nilai atau situasi dan kondisi faktual bahkan opini yang dikaji dari sudut nilai. Ketika informasi nilai disampaikan pada seseorang atau kelompok, maka informasi tersebut akan direspon secara kognitif dan afektif oleh orang yang bersangkutan. Informasi nilai yang disampaikan pada seseorang akan mempengaruhi belief (keyakinan) penerima. Keyakinan yang dimaksud adalah kepercayaan seseorang terhadap informasi nilai. Informasi nilai akan cepat diyakini si penerima bila sejalan dengan keyakinan yang telah ada, atau dapat diterima oleh logika rasionalnya. Sehingga informasi tersebut dapat memperluas atau mempertebal keyakinannya.

Rangkaian informasi nilai yang telah menjadi keyakinan individu akan mempengaruhi sikap (attitude) seseorang dalam bertindak. Sikap tersebut akan dicerminkan dalam pilihannya. Oleh karena itu, pilihan dan keputusan seseorang dapat mencerminkan keyakinannya. Setiap harinya masingmasing individu selalu dihadapkan dengan pilihan dan keputusan tersebut. Semakin lama keyakinan yang menjadi pendorong sikap dan keputusannya akan semakin terpola, terbentuk, dan melembaga. Sehingga keyakinan itulah yang menjadi prinsip penting dalam hidupnya, bahkan menjadi standar untuk menentukan baik buruk dan benar salah serta layak tidaknya sebuah perbuatan, sehingga keyakinan itu telah menjadi nilai dalam dirinya. 
Nilai yang terus menerus menjadi prinsip diri dan terlembagakan dalam diri melalui proses interaksi dengan lingkungan (keluarga, masyarakat, organisasi) diaktualisasikan dalam kehidupan, baik dalam bentuk ucapan maupun perbuatan. Sifat diri yang melembaga tersebut menjadi watak atau karakter seseorang. Setiap orang memiliki karakter (sifat atau watak) masing-masing. Karakter seseorang yang berlandaskan pada nilai yang membedakan dirinya dengan orang lain disebut kepribadian. Kepribadian adalah watak khas yang dimiliki seseorang yang membedakan dirinya dengan orang lain. Ketika nilai sudah menjadi kepribadian seseorang, maka nilai itu menjadi identitas, menjadi ciri pribadi yang bersangkutan. Bukan hanya dikenal dirinya, tetapi juga dikenal oleh orang lain. Sehingga sering ditemukan sebutan "dia disiplin, dia bersih, dia religius" serta sebutan lain yang menandakan watak seseorang. Nilai yang telah menjadi keyakinan akan mendorong sikap dan perbuatan yang dianggap penting, sehingga menjadi prinsip diri dan berlangsung terus menerus menjadi watak sehingga membentuk sebuah kepribadian yang membedakan dirinya dari orang lain. Hal itu dapat dipertahankan tanpa melihat risiko demi tegaknya nilai tersebut. Dalam hal ini sudah tidak lagi melihat untung rugi dan bahkan melampaui standar hukum dan kaidah masyarakat yang berlaku untuk menegakan nilai yang menjadi prinsipnya. Sehingga nilai yang demikian sudah menjadi jati dirinya (dignity).

Selain dengan menginternalisasikan nilai agama dalam membentuk karakter anak, lingkungan juga menjadi faktor yang memberi pengaruh dalam membentuk karakter anak. Lingkungan di mana anak berada, melakukan interaksi, bermain, dan bersosialisai dengan tetangga, menjadikan unsur penting dalam Pendidikan. Hal ini memberikan pengaruh dan warna dalam kepribadian dan karakter anak karena anak berinteraksi dan mengamati secara langsung lingkungan di mana dirinya berada, sehingga apa yang ditonton menjadi tuntunan (Framanta, 2020). Pengaruh lain dari lingkungan sosial ada yang dapat langsung diterima dan ada pula yang sebaliknya. Misalnya pergaulan sehari-hari, pergaulan dengan keluarga, teman sebaya, teman bermain, dan lain sebagainya(Fauziddin, 2014).

Pentingnya pendidikan agama dalam membentuk karakter anak merupakan suatu langkah terbaik yang dilakukan oleh orang tua muslim yang memiliki kewajiban dalam menjaga dan melindungi keluarganya dari segala hal yang dapat menjerumuskannya pada kesesatan dan api neraka. Hal yang dilakukan harus selaras dengan nilai-nilai agama, diantaranya mendidik anak untuk berperilaku sesuai ajaran agama, hidup berdampingan dengan tetangga, menjaga silaturahim, serta menjadi pribadi yang baik secara individu dan sosial (Ruli, 2020)

Berdasarkan hasil pengelolaan angket pada pertanyaan nomor lima dari 22 responden diperoleh data bahwa lebih khususnya terhadap orang tua yang menjadi circle utama dalam pendidikan agama dan karakter. Pendidikan Islam juga perlu dibangun dalam setiap keluarga sebagai pondasi yang kuat, 
menjadikan Al-Qur'an dan As-Sunah sebagai pedoman dalam mendidik anak. Memperbanyak materi keagamaan baik di rumah ataupun lembaga pendidikan. Sehingga orang tua yang berperan sebagai pendidik yang pertama dan utama dapat menciptakan nuansa yang harmonis dalam bingkai agama dalam kehidupan keluarga, dengan membimbing, mengenalkan, memberi keteladanan, serta melibatkan anak-anak untuk melaksanakan ajaran agama dalam kehidupan sehari-hari (Taubah, 2015).

Pentingnya pendidikan agama yang di aktualisasikan dan di realisasikan melaui akhlak untuk anak sangatlah penting untuk dilakukan. Hal tersebut karena dalam siklus kehidupan manusia periode anak merupakan masa di mana pada masa ini menjadi paling penting dan terekam kuat dalam memori anak. Pendidikan yang berlandaskan nilai-nilai Islam yang diterapkan oleh orang tua kepada anaknya mempunyai tujuan agar anaknya tumbuh dan berkembang menjadi pribadi yang beriman serta bertaqwa kepada Allah SWT, berakhlak mulia yang mencakup moral, etika, budi pekerti spiritual atau pengalaman nilai dan pemahaman nilai-nilai keagamaan yang di aktualisasikan dalam kehidupan sehari-harinya (Yuliaharti, 2018). Sehingga pentingnya pendidikan Islam dalam membentuk karakter anak dapat mempengaruhi perkembangan anak sesuai karakter yang Islami, baik pendidikan yang dilakukan orang tua, masyarakat, lingkungan maupun oleh guru. Pendidikan berlandaskan agama Islam diakui sangat penting untuk ditegakkan dan digunakan untuk pembentukan karakter seorang anak (Parhan, 2020). Sebisa mungkin orang tua membentengi diri anaknya dengan ajaran-ajaran Islam, bersikap seselektif mungkin untuk menentukan dan mengetahui lingkungan sekitar anaknya. Dengan menginternalisasikan nilai agama, maka pandangan hidup akan mewarnai perkembangan jasmani dan akalnya, serta penanaman sikap berlandaskan nilai Islam yang dikemudian hari akan menjadi basis dan pondasi dalam menghargai sesama dalam berinteraksi dengan sesama (Ahmad Tafsir, 2010).

\section{KESIMPULAN}

Pendidikan dan pembentukan karakter sedari dini/kecil sangatlah penting, karena mempunyai pengaruh besar untuk kehidupan seorang anak kedepannya. Banyak aspek yang harus diperhatikan dalam mendidik karakter seorang anak, salah satunya adalah Pendidikan Agama Islam. Banyak orang tua merasa bahwa menanamkan nilai-nilai Islam kepada anak sejak dini sangatlah penting karena anak akan memiliki dasar agama yang cukup kuat dengan berpegang teguh pada Al-Qur'an dan Hadist. Lingkungan menjadi salah satu faktor yang sangat berpengaruh dalam tumbuh kembang seorang anak atau individu. Hal tersebut karena lingkungan merupakan sebuah tempat yang berisi banyak orang dengan latar belakang yang heterogen. Apabila lingkungan tersebut kurang baik, maka 
dapat berpengaruh buruk bagi pembentukan karakternya. Oleh sebab itu, pentingnya orang tua dan anak harus selektif dalam menentukan dan membentengi diri dari pengaruh buruk.

\section{DAFTAR PUSTAKA}

A'yun, Q., Prihartanti, N., \& Chusniatun, C. (2015). PERAN ORANG TUA DALAM PENDIDIKAN ANAK USIA DINI (Studi Kasus Pada Keluarga Muslim Pelaksana Homeschooling). Indigenous: Jurnal Ilmiah Psikologi, 13(2), 33-40.

https://doi.org/https://doi.org/10.23917/indigenous.v13i2.2601

Ahmad Tafsir. (2010). Metodologi Pengajaran Agama Islam. PT. Remaja Rosda Karya.

Alawi, A. H. I. (2019). Pendidikan Penguatan Karakter Melalui Pembiasaan Akhlak Mulia. Qiro'ah: Jurnal Pendidikan Agama Islam, 9(1), 16-29.

https://doi.org/https://doi.org/10.33511/qiroah.v9i1

Azis, S. (2017). Pentingnya Pendidikan Agama Islambagi Orang Tua dalam Mendidik Anak. AdzZikr: Jurnal Pendidikan Agama Islam, 2(2), 12-28.

Djaelani, M. S. (2013a). Peran Pendidikan Agama Islam dalam Keluarga dan Masyarakat. Jurnal Ilmiah Widya, 1(2).

Djaelani, M. S. (2013b). PERAN PENDIDIKAN AGAMA ISLAM DALAM KELUARGA DAN MASYARAKAT. Juenal Ilmiah Widya, 1(2), 100-105.

Erzad, A. M. (2018). Peran Orang Tua Dalam Mendidik Anak Sejak Dini Di Lingkungan Keluarga. ThufuLA: Jurnal Inovasi Pendidikan Guru Raudhatul Athfal, 5(2), 414-431.

Fauziddin, M. (2014). Pembelajaran PAUD Bermain, Cerita, dan Menyanyi secara Alami. PT. remaja Rosdakarya.

Framanta, G. M. (2020). Pengaruh Lingkungan Keluarga Terhadap Kepribadian Anak. Jurnal Pendidikan Dan Konseling, 1(2), 126-129.

https://doi.org/https://doi.org/10.31004/jpdk.v1i2.654

Gade, F. (2012). Ibu Sebagai Madrasah Dalam Pendidikan Anak. Jurnal Ilmiah Didaktika: Media Ilmiah Pendidikan Dan Pengajaran, XIII(1), 31-40. https://doi.org/http://dx.doi.org/10.22373/jid.v13i1.462 
Hakam, K. A. (2016). Internalisasi Pendidikan Karakter di Sekolah Dasar. Disampaikan Dalam Seminar Nasional Di Universitas Indonesia Tahun 2015, Disajikan Di Balai Besar Pelatihan Kesehatan Jakarta 2016, Dan Seminar Nasional Di Institut Hindu Dharma Negeri (IHDN) Denpasar Tahun 2016.

Hardjasujana, \& Ahmadslamet. (1999). Evaluasi keterbacaan: buku teks bahasa Sunda untuk Sekolah Dasar di Jawa Barat. Pusat Pembinaan dan Pengembangan Bahasa, Departemen Pendidikan dan Kebudayaan.

Husin, N. (2016). Hadits-Hadits Nabi Saw Tentang Pembinaan akhlak. Jurnal An-Nur, 4(1), 14-40.

Mansur, A. (2000). Cara Mendekatkan Diri Pada Allah. Grafindo Persada.

Muhaimin. (2012). Pengembangan Kurikulum Pendidikan Agama Islam di Sekolah, Madrasah, dan Perguruan Tinggi. PT Raja Grapindo Persada.

Muthmainnah, M. (2012). Peran Orang Tua dalam Menumbuhkan Pribadi Anak yang Androgynius Melalui Kegiatan Bermain. Jurnal Pendidikan Anak, 1(1), 103-112. https://doi.org/https://doi.org/10.21831/jpa.v1i1.2920

Novrinda, Kurniah, N., \& Yulidesni. (2017). PERAN ORANGTUA DALAM PENDIDIKAN ANAK USIA DINI DITINJAU DARI LATAR BELAKANG PENDIDIKAN. Jurnal Ilmiah Potensia, 2(1), 39-46. https://doi.org/https://doi.org/10.33369/jip.2.1.39-46

Parhan, M. (2018). KONTEKSTUALISASI MATERI DALAM PEMBELAJARAN. ADI WIDYA: Jurnal Pendidikan Dasar, 3(1), 7-18. http://ejournal.ihdn.ac.id/index.php/AW

Parhan, M., Faiz, A., Karim, A., Nugraha, R. H., Subakti, G. E., Islamy, M. R. F., Budiyanti, N., Fuadin, A., \& Tantowi, Y. A. (2020). Internalization values of Islamic education at university. International Journal of Psychosocial Rehabilitation, 24(8), 14778-14791. https://doi.org/10.37200/IJPR/V24I8/PR281455

Parhan, M., Islamy, M. R. F., Budiyanti, N., Nugraha, R. H., \& Hyangsewu, P. (2020). Responding to Islamophobia by Internalizing the Value of Islam Rahmatan lil Alamin through Using the Media. Islam Realitas: Journal of Islamic and Social Studies, 6(2), 137-149. https://doi.org/http://dx.doi.org/10.30983/islam_realitas.v6i2.3695

Parhan, M., \& Kurniawan, D. P. D. (2020). Aktualisasi Peran Ibu Sebagai Madrasah Pertama Dan Utama Bagi Anak Di Era 4.0. JMIE (Journal of Madrasah Ibtidaiyah Education), 4(2), 157. https://doi.org/10.32934/jmie.v4i2.193 
Parhan, M., \& Sutedja, B. (2019). PENERAPAN PENDEKATAN PEMBELAJARAN KONTEKSTUAL DALAM PENDIDIKAN AGAMA ISLAM DI UNIVERSITAS PENDIDIKAN INDONESIA. TARBAWY: Indonesian Journal of Islamic Education, 6(2), 114-126. https://doi.org/10.17509/t.v6i2.20165

Perni, N. N. (2019). Pentingnya Menciptakan Suasana Pembelajaran Bagi Anak Usia Dini. Pratama Widya: Jurnal Pendidikan Anak Usia Dini, 2(2), 45-50.

https://doi.org/http://dx.doi.org/10.25078/pw.v2i2.1015

Ramayulis. (2012). Ilmu Pendidikan Islam. Kalam Mulia.

Rufaedah, E. A. (2020). PERANAN PENDIDIKAN AGAMA DALAM KELUARGA TERHADAP PEMBENTUKAN KEPRIBADIAN ANAK-ANAK. Counselia; Jurnal Bimbingan Konseling Pendidikan Islam, 1(1), 8-25.

Ruli, E. (2020). TUGAS DAN PERAN ORANG TUA DALAM MENDIDK ANAK. Jurnal Edukasi NonFormal, 1(2), 143-146.

Sari, D. P. (2017). Pendidikan Karakter Berbasil Al-Qur'an. Islamic Counseling Journal, 1(1), 1-24.

Setiardi, D. (2017). Keluarga Sebagai Sumber Pendidikan karakterbagi Anak. Tarbawi: Jurnal Pendidikan Islam, 14(2), 136-146.

Setiawan, E. (2017). Konsep Pendidikan Akhlak Anak Perspektif Imam Al Ghazali. Jurnal Kependidikan, 5(1), 43-54. https://doi.org/oi.org/10.24090/jk.v5i1.1252

Setyosari, P. (2016). Metode Penelitian Pendidikan \& Pengembangan. Kencana.

Sukring. (2013). Pendidikan Agama Islam. Kaukaba Pressindo.

Syam, J. (2016). Pendidikan Berbasis Islam yang Memandirikan dan Mendewasakan. EduTech: Jurnal Ilmu Pendidikan Dan Ilmu Sosial, 2(2), 73-83.

https://doi.org/http://dx.doi.org/10.30596\%2Fedutech.v2i2.600

Tahang, J. H. (2010). URGENSI PENDIDIKAN AGAMA DALAM KELUARGA TERHADAP PEMBENTUKAN KEPRIBADIAN ANAK. HUNAFA: Jurnal Studia Islamika, 7(2), 163-178. https://doi.org/https://doi.org/10.24239/jsi.v7i2.99.163-178

Taubah, M. (2015). PENDIDIKAN ANAK DALAM KELUARGA PERSPEKTIF ISLAM. Jurnal Pendidikan Agama Islam, 3(1), 109-136.

https://doi.org/https://doi.org/10.15642/jpai.2015.3.1.109-136 
Towoliu, I. D., Hartati, S., \& Hapidin, H. (2021). Pendidikan Karakter Berbasis Islam melalui Program Cinta Rosul pada Anak Taman Kanak-Kanak. Jurnal Obsesi : Jurnal Pendidikan Anak Usia Dini, 5(1), 521-529. https://doi.org/10.31004/obsesi.v5i1.618

Yuliaharti. (2018). Pembentukan Karakter Islamidalam Hadis Dan Implikasinya Pada Jalur Pendidikan Non Formal. POTENSIA: Jurnal Kependidikan Islam, 4(2), 216-228. https://doi.org/http://dx.doi.org/10.24014/potensia.v4i2.5918 